\title{
Meaning, necessity, and value of obedience according to the sidra "Lech- lech" in rabbinical tradition
}

\author{
[Smysl, nezbytnost a hodnota poslusnosti podle sidry „Lech-lecha“ \\ $\mathrm{v}$ rabinske tradici]
}

\author{
Marie Roubalova - Bojan Zalec - Roman Kralik
}

DOI: 10.18355/XL.2018.11.02.05

\begin{abstract}
Sidra Lech lecha (Bereshit / Genesis 12,1 - 17,27) is an important passage in the book of Bereshit. The authors of the study analyze the understanding of the text from the point of view of various rabbinical traditions. They focus on the theological and ethical aspects of the creation narrative. They emphasize the concepts of revelation, belief, covenant, and obedience as essential entry points for valid applications of the hermeneutical approaches that inform the writing of the story of Abraham. In this study, they focus on the narrative of Abraham from the perspective of an internal struggle between the obedient faith of an individual and external constraints required by the covenant between God and humans in which the one and ultimate guarantor is the God of Abraham. This covenant reveals the cognitive as well as mystical aspects of the individual's struggle for genuine selfrealization, a spiritual growth that is propelled by one's anticipation of the future as determined by the covenantal promise of God.
\end{abstract}

Key words: Sidra, Abraham, God, Obedience, Genesis

\section{Anotace:}

Sidra Lech lecha (Berešit/Geneze 12,1 - 17,27) je důležitou pasáží v knize Berešít. Autoři studie analyzují porozumění textu z pohledu různých rabínských tradic $\mathrm{s}$ ohledem zejména na teologicko - etické aspekty. Zdůrazňují přitom koncept zjevení, víry, smlouvy a poslušnosti jako zásadní os pro validní aplikace uváděných hermeneutických př́stupů, která je demonstrována na př́běhu Abraháma. V uvedené studii se narace Abrahama stává tvůrčí platformou odhalující zajímavou dialektiku života a smrti ve smyslu interního autentického zápasu poslušné víry jednotlivce a externích faktorů, které jsou garantovány smlouvou mezi Bohem a člověkem, přičemž jediným a konečným garantem je Bůh. Tato smlouva odkrývá kognitivní i mysteriózní aspekty zápasu člověka usilujícího o pravdivou aktualizaci svého bytí, která je ukotvena $\mathrm{v}$ anticipaci budoucna, jež je určeno zaslíbením Božím.

Klíčové slova: Sidra, Abrahám, Bůh, poslušnost, genesis

\section{Úvod}

Sidra (,parašat hašavua“) je název oddílu Torat Moše, který je veřejně čten při šabatové synagogální bohoslužbě. (JT, Berachot 3:1, 6b; JT, Bejca 1:6, 60,c) Toto označení je běžně používáno již v Babylónském a Jeruzalémském talmudu. (BT, Šabat 116b; BT, Joma 87a; JT, Taanit 1:6, 60c) Synagogální čtení („kriat hatóra“) př́íslušné sidry daného týdne probíhá po modlitbách, požehnáních a prosbách ranní bohoslužby (,šacharit“) o šabatu. Sidra se předčítá, sejde-li se při veřejné bohoslužbě minimálně deset dospělých (počet mužů může býtv krajním př́padě doplněn na deset také jedním chlapcem před „bar micva“ - (SLADEK, 2008: 155) mužů tzv. „minjan“ (dosl. „počet“), protože v takovém př́ípadě je př́tomna i „Šechina“ (Boží př́itomnost) (BT, Berachot 6a) Celá Tóra je přečtena po jednotlivých sidrách během jednoho roku. Vedle této praxe (původně babylónské), která se postupně prosadila, existoval také tříletý cyklus používaný původně v Erec Jisrael.

\section{Význam sidry}

XLinguae, Volume 11, Issue 2, April 2018, ISSN 1337-8384, eISSN 2453-711X 
Příslušné sidře je věnována velká pozornost i během celého předchozího týdne. Zbožní muži (ženy jsou od povinnosti připravovat se na sobotní čtení Tóry osvobozeny (Rambam, Talmud Tóra 1,1; Šulchan aruch, Jore dea 246,6), studium jim však není zakazováno a také jim za to náleží odměna jako někomu, kdo nemusí plnit micvu a přesto ji plní (Mišna berura 282,12; Aruch hašulchan 282,11; Chazon Ovadja, Šabat 1,328). Spor rabínů Eleazara a Azaje týkající se tohoto tématu zachycuje již Mišna (Sota 20) - pozn, autorů) začínají studovat příslušnou sidru již po odpolední bohoslužbě (,mincha“) o předchozím šabatu, (Mišna berura 285.7) nebo s četbou nové sidry začínají následující den ráno. (Kicur šulchan aruch 72,11) Sidru čtou hlasitě (BT, Eruvin 54a; Rambam, Talmud Tóra 3,12; Šulchan aruch, Jore dea 246,22; Kicur šulchan aruch 27,5) zpravidla po menších částech nazývaných ,alijot“, tj. jedna „alija“ během každého dne týdne a čtení i studium sidry končí v pátek.(Aruch hašulchan 285,1; Mišna berura 285,8) V pátek ráno po ranní bohoslužbě (někteří v pátek odpoledne) čtou muži sidru ještě jednou celou (pro toho kdo zanedbal předchozí studium je tento čas téměř poslední možností nápravy). (Tur 285,3) Příprava na sobotní čtení sidry musí být dokončena nejpozději v sobotu ráno před ranní bohoslužbou (,„̌sacharit“), tj. před čtením textu sidry v synagoze (Mišna berura 285,9) „Lech-lecha“ je třetí sidra Tóry následující v ročním cyklu synagogálních čtení po sidrách „Beršit“ a „Noach“. Sidra „Lech-lecha“ se čte třetí sobotu po svátku Simchat Tóra (Radost z Tóry). V Izraeli se svátek Simchat Tóra slaví 22. tišri zároveň se svátkem Šemini aceret, v diaspoře se slaví následující den 23. tišri. Den na který připadá svátek Simchat Tóra se často označuje také jako „Jom beracha“ („Den požehnání“), podle názvu oddílu Tóry „Vezot beracha“, který je tento den veřejně předčítán nebo „Jom sijum“ („Den ukončení), protože tento den končilo roční veřejné předčítání Tóry. „Lech-lecha“ zahrnuje text knihy Berešit od dvanácté kapitoly (prvního verše) až po sedmnáctou kapitolu (dvacátého sedmého verše). Podle počtu vyvolaných k synagogánímu čtení se každá sidra člení na sedm menších částí - „alijot“ (sg. „alija“; odvozeno od hebrejského slovesa „ala“ „stoupal, šel nahoru“, kterým se mimo jiné označuje příchod do zaslíbené země). Alija je výstup na vyvýšené místo s pultíkem (bima, almemor) v synagoze určené ke čtení textu sidry ze svitku. Sidra „Lech-lecha“ se člení na alijot: Berešit 12,1-13; 12,14-13,4; 13,5-18; 14,1-20; 14,21-15,6; 15,7-17,6 a 17,7-27). Podle tradičního způsobu zápisu na svitek obsahuje sidra „Lech-lecha“ 6336 písmen, 1686 slov, 126 veršů a jednu micvu („brit mila“ - „smlouva obřízky“). (Srv. Vajikra 12,3)

\section{Výzva Abrahamovi}

Název „Lech-lecha“ vychází z počátečních slov sidry - „Řekl Hospodin Abramovi““ (vzhledem k rabínské tradici dále jen Abraham) - Od chvíle, kdy Bůh změnil Abramovi („Otec je vyvýšený“) jméno na Abraham („Otec hlučíčího davu“), má být nazýván jen jménem Abraham: „Kdo tak nečiní přestupuje podle rabínské tradice pozitivní př́ikaz: „Tvé jméno bude Abraham...“ a zároveň přestupuje negativní př́íkaz: „Nebudeš se již nazývat Abram..." (BT, Berachot 13a).: "Jdi si („Lech-lecha“) ze své země...“. (Berešit 12,1) Odkazuje tak na Hospodinovu výzvu k Abrahamovi, kterou lze přeložit slovy „Jdi si““. (Berešit 12,1) Abraham se ve chvíli, kdy zaznívá tato výzva ocitá v mezní situaci, kdy musí pečlivě hodnotit a svobodně si zvolit, zda poslechne Boha a půjde do neznámé země nebo neposlechne a zůstane. Bůh mu v tomto rozhodování pomáhá zaslíbením, které je ve výzvě „Lech-lecha“ obsaženo: „Jdi kvůli sobě!“, „Je to ve tvém vlastním zájmu!“, „Bude ti to ku prospěchu!“. Tímto způsobem chápe název sidry Rabi Šelomo Jicchaki (dále jen Raši), když uvádí: „Odeber se pro svůj užitek a pro své dobro.“. (Raši k Berešit 12,1). S názorem Rašiho, který slovnímu spojení „Lech lecha“ přikládá zvláštní obsah a důraz, nesouhlasí Ramban, který se domnívá, že jde o běžné vyjadřování tanachické hebrejštiny, kde druhé slovo („lecha“) nemá žádný zvláštní význam: „Pro svůj prospěch a pro své dobro - to je jazyk Rašiho. Ale není to nutné, protože je to bežný způsob vyjádřování hebrejštiny viz: „,hagešem chalaf halach lo - lijavec přešel, je ten tam“/Šir haširim 2,11 , ,elcha li - chci jít“ /Jirmejahu 5,5/“, ,ivru lachem et nachal - Přejděte potok!“ (Devarim 2,13) a mnoho dalších výskytů (Ramban $\mathrm{k}$ Berešit 12,1). Ramban však zmiňuje (k Berešit 12,1) i další interpretaci předložky lamed s pronominálním sufixem uváděnou již rabíny v Talmudu 
(BT, Joma 3,72), když odkazuje na texty „psol lecha - Vytesej si!“ (Devarim 10,1) a „ase lecha - Udělej si!“ (Bemidbar 10,2). Další výklad přináší rabi Meir Loev ben Jechiel Michael Weiser (Malbim), který se domnívá, že „lech lecha“ má doslovný význam a znamená „Jdi k sobě!“. Avraham byl podle něj pod negativním vlivem své rodné země, pohanského města, modlářských rodičů a bylo podle něj nezbytné, aby nalezl svou vlastní identitu - „aby šel k sobě“. V nepunktovaném textu mají obě slova stejný tvar. Z tohoto důvodu mohlo původně jít pouze o dvojí opakování imperativu „Jdi!“‘, které vyjadřovalo intenzitu a naléhavost - „Jdi!“”, „Jdi!““ ve významu: „No tak, jdi už přece!““. Další zaslíbení (potomstvo, země, majetek a dobrá pověst) obsažená v této sidře jsou vlastně komenářem k této Boží výzvě. „Lech-lecha“ je nejen výzvou k fyzické cestě do zaslíbené země, ale především výzvou k duchovní cestě hledání Boží vůle. Putování člověka po světě omezuje (podle Rašiho k Berešit 12,2) možnost mít potomstvo, majetek a dobrou pověst. Z tohoto důvodu se Abrahamovi dostává trojího požehnání: rozmnožení potomstva (počtem i významem), dar země a dobré jméno. Bůh slibuje Abrahamovi rozmnožení potomstva a požehnání nejen pro něj, ale také pro všechny čeledi země. Po kletbách, které zazněly po neposlušnosti Adama a Chavy, dochází v sidře „Lech-lecha“ k obratu. Požehnání povede přes Izáka. Vytvoření Božího lidu není jen záležitostí krve, ale především postojem poslušnosti $\mathrm{k}$ Božímu učení a př́kazům. Potomci, kterým budou tyto věci lhostejné, se požehnáním nestanou. Rozmnožení vyvoleného lidu je dílem Božím. Převezme-li tento úkol na svá bedra člověk, tak jak to udělala Sára, když Avrahamovi poskytla svou egyptskou otrokyni, nevede to $\mathrm{k}$ ničemu dobrému, naopak Jišmael a jeho potomci trvale ohrožují Boží lid. Vyjití poslušného Abrahama se stane paradigmatem - v budoucnu stále opakovaném jednotlivci i celým vyvoleným lidem. Lid vychází z egyptského otroctví, babylonského zajetí i z armagedonu druhé světové války, aby se vrátil do země, kterou Bůh slíbil poslušným potomkům Abrahama.

\section{Eticko - teologický význam}

Sidra „Lech-lecha“ se dotýká nejvýznamnějších teologických a etických témat, která jsou v Tanachu obsažena. $Z$ teologických témat je to především: zjevení, víra a smlouva. Sidra zmiňuje dvě smlouvy. První z nich je „Berit bejn habetarim“ („Smlouva mezi rozdělenými díly“, Berešit 15,9-21). druhou smlouvou je „Berit mila“ („Smlouva obřízky“, Berešit 17). Obříza jako znamení smlouvy poukazuje na to, že tato smlouva se netýká pouze Abrahama, ale vztahuje se na jeho potomstvo. Abraham je prvním z mnoha jednotlivců, kteří budou ,̌rezáni““ obdobně jako byly řezány obětní kusy (betarim) dobytka.

Z velkých etických témat se týká otázek postavení jednotlivce před Bohem, spoluodpovědnosti člověka za své bližní a nasazení vlastního života pro druhé. Motiv, který v této sidře propojuje teologická a etická témata, je hodnota poslušnosti. Sidra zachycuje různé roviny v nichž může být tato poslušnost realizována. Většina veršů sidry „Lech-lecha“, které se tématu poslušnosti týkají, obsahuje imperativ (v některých př́padech dokonce zesílený), který vyžaduje rozhodnutí jednotlivce, zda poslechne či nikoliv. Poslušnost (případně neposlušnost) se v této sidře zobrazuje v reakci člověka: (1) na rozkaz Boží („,Jdi si /ze své země/!“" (Berešit 12,1), ,Jdi projdi /tu zemi/“ (Berešit 13,17), „Procházej se před mou tváŕí a bud’ dokonalý!“ Berešit 17,1), (2) na rozkaz Božího posla („Vrat' se /ke své paní/ a pokoř se!“ - Berešit 16,9), (3) na př́kaz manžela manželce („Ř́kej, že jsi má sestra!“ - Berešit 12,13) nebo manželky manželovi („Vejdi k mé služce!“ - Berešit 16,2), (4) na rozkaz vládce určený poddanému („Vezmi /svou manželku/ a jdi!“ Berešit 12,20) nebo jinému vládci (,Dej mi duši /lidi/ - Berešit 14,21) a (5) na rozkaz bližnímu („Odděl se prosím ode mne!“ - Berešit 13,9). V jiných př́ípadech je místo imperativu použit indikativ, který ani nepřipouští jinou možnost než poslušnost („Budeš dodržovat mou smlouvu!“ Berešit 17,9, „Obřežete!“ Berešit 17,11) nebo je použita figura etymologica („Obřezáním bude obřezán“ - „Určitě bude obřezán“ Berešit 17,13).

\section{Sidra „Lech-lecha“ jako poslušnost}


Sidra „Lech-lecha“ ukazuje poslušnost jako správnou cestu, uposlechne-li člověk Boha (nebo autoritu, která jej zastupuje) a jako nesprávnou cestu, poslouchá-li člověk slepě toho, kdo se Boží vưli vzpouzí. Substantivum „poslušnost“ zahrnuje v českém jazyce slovo „slušnost“, což navozuje dojem, že poslušnost je věcí slušnosti či dobrého chování. Poslušné dítě by v takovém prrípadě bylo dítě, které se chová slušně, aniž by toto konstatování cokoli vypovídalo o vztahu dítěte $\mathrm{k}$ tomu, koho poslouchá. Teprve při bližším zkoumání etymologie slova „poslušnost“ v indoevropských jazycích si lze povšimnout vztahu tohoto slova se slovesem „slyšel“, protože poslušnost má svůj základ ve slyšení. V semitských jazycích je tato souvislost zcela zřetelná. V hebrejštině sloveso „šama“ znamená „slyšel““ (naslouchal) a zároveň „poslouchal“ (byl poslušný). Poslušnost tak zřetelně souvisí se slyšením: „Doslovný smysl poslušnosti tedy označuje připravenost poslouchat vůli někoho druhého a provádět ji““. (Peschke, 1999:Sidra Lech lecha (Bereshit / Genesis $12,1-17,27)$ is an important passage in the book of Bereshit. The authors of the study analyze the understanding of the text from the point of view of various rabbinical traditions. They focus on the theological and ethical aspects of the creation narrative. They emphasize the concepts of revelation, belief, covenant, and obedience as essential entry points for valid applications of the hermeneutical approaches that inform the writing in the story of Abraham. In this study, they focus on the narrative of Abraham from the perspective of an internal struggle between obedient faith of an individual and external constrains required by the covenant between God and humans in which the one and ultimate guarantor is the God of Abraham. This covenant reveals the cognitive as well as mystical aspects of the individual's struggle for genuine self-realization, a spiritual growth that is propelled by one's anticipation of the future as determined by the covenantal promise of God.

468). Poslušnost v tomto případě je věcí osobního vztahu. Dítě není poslušné, protože je slušně vychované, poslouchá, protože má vztah $\mathrm{k}$ tomu, koho slyší a kdo po něm něco žádá. Chtít po člověku poslušnost bez tohoto osobního vztahu je marnost.

Poslušnost v současné době není samozřejmostí už proto, že současný člověk chce být čím dál tím víc nezávislý. Nechce se podřizovat autoritám, zdůrazňuje svou svobodu a při tom všem zpravidla nevidí své zotročení. Tím se postoj k poslušnosti v současné společnosti liší od postoje $\mathrm{v}$ dobách starověkého Izraele. Poslušnost vůči Bohu a také vůči otci a matce (a dalším autoritám), dosvědčujícím svými skutky i slovy víru a lásku k Bohu, je základní postoj vyznavače Boha Izraele. Poslušnost byla smyslem a cílem jeho života. Poslušný člověk se prochází s Bohem, naslouchá mu a vodí po jeho cestách své děti. Tato poslušnost však není „slepou“ poslušností. Člověk má svobodnou vůli, přemýšlí o tom, co je dobré a co je zlé, co je moudré a co je pošetilé a na základě toho se rozhoduje - volí. Možnost volby byla dána člověku již v zahradě Eden, kdy se mohl rozhodnout, zda bude či nebude jíst plody ze stromu poznání dobrého a zlého. Svou volbou člověk rozhoduje o tom, jak naloží se svým životem, zda zůstane v Boží zahradě nebo z ní bude vyhnán. V případě, že se rozhodne správně, zůstane v Boží blízkosti, rozhodne-li se nesprávně, ocitá se na počátku dlouhé a strastiplné cesty.

Neposlušnost je v dnešní době líbivá. Každý rebel je vítán, protože rozčeří nudu všednosti. Neposlušnost ve starověkém Izraeli je oproti tomu děsivá. Je to hř́ích, sejití z Božích cest, minutí cíle, utrpení a smrt. Mezní situace (boje, nemoc, utrpení apod.) mohou člověka zastavit a vrátit na správnou cestu. Také na správných cestách je poslušnost vyznavačů jediného Boha neustále prověřována. Abraham je podle Mišny vyzkoušen v průběhu svého života sérií deseti zkoušek (desítka je číslo plnosti - Mišna, Pirkej avot $5,4)$. Rabínské autority se shodují na počtu zkoušek, ale liší se $v$ jejich přesném výčtu. Seznam uvedený v Mišně (obdobně také u Moše ben Majmona) obsahuje pouze zkoušky zaznamenané v Tóře - vyjití z rodiště, hlad v zaslíbené zemi, (,Aby ho vyzkoušel, zda bude rozmýšlet o slovech Svatého, bud' pochválen, který mu řekl, aby šel do země Kenaan“ Raši k Berešit 12,10). Sára v moci faraóna, boj s nepřátelskými králi, Hagar a její potomek, obřízka, Sára v moci krále Geraru, vypuzení Hagar, odloučení od Jišmaela, svázání Jicchaka (Moše ben Maimon, Komentář k Mišně, Pirkej avot 5,4). Midraše (Výrazem „midraš“ (výklad, bádání) je označován typ židovské literatury, který obsahuje kázání nebo výklady textu Tanachu často pomocí podobenství a př́běhů. Midraše se dělí na agadické a hlachické (podle typu výkladu) a na exegetické a homiletické (podle literární formy - pozn. 
autorů) uvádí i zkoušky o kterých Tanach mlčí (např. třináctileté věznění Abrahama králem Nimrodem a jeho uvržení do ohnivé pece). (Berešit raba 38,11)

Obdobně jako Bůh zkoušel Abrahama, zkouší každého člověka. Bůh k člověku mluví a chce, aby mu naslouchal a poslouchal jej. Nechce slušné chování, ale chce živý vztah, naplněný láskou (protože Bůh je milostivý), bázní (protože Bůh je spravedlivý) a poslušností (protože Bůh mluví a chce, abychom jej slyšeli a poslouchali). Měřítkem této poslušnosti nemohou být lidské pocity, představy a dokonce ani vnitřní kompas člověka, kterému se ř́ká svědomí. Měřítkem poslušnosti je Tóra, jak ji Bůh zjevil svému vyvolenému lidu.

V sidře „Lech-lecha“ je podle rabínské tradice naznačeno napětí mezi poslušností vůči Bohu a poslušností vůči otci, který není zástupcem Boha v rodině. S otázkou, zda při „vyjití“ poslouchá Abraham Boha nebo otce, souvisí otázka, zda k „vyjití“ došlo z Uru nebo z Charánu. V sidře „Noach“, která předchází sidře „Lech-lecha“, je zaznamenán rodokmen Š́mův. V něm je uvedeno, že Terach (ve věku sedmdesáti let) zplodil Abrahama (Abrama), Náchora a Hárána (Berešit 11,26-27. Z uvedeného pořadí synů $\mathrm{v}$ tomto textu lze předpokládat, že Abraham z nich byl nejstarší. Tímto způsobem chápe text také Bereši raba 38,14, která se domnívá, že mezi jednotlivými syny byl vždy roční odstup. Text knihy Berešit však nevylučuje, že Terachovi bylo sedmdesát let při narození všech tř́ synů) a dále, že Háran umřel před svým otcem Terachem v rodné zemi v Kaldéjském Uru. Z uvedeného vyplývá, že mezi narozením Teracha a Abrahama uběhlo sedmdesát let a že jejich rodištěm byl Kaldéjský Ur. Odtud vyšla Terachova rodina směrem do zaslíbené země: „I vzal Terach svého syna Abrama a vnuka Lota, syna Háranova, a snachu Sáraj, ženu svého syna Abrama, a vyšli spolu z Kaldejského Uru. Cestou do země kenaanské přišli do Cháranu a usadili se tam.“ (Berešit 11,31) Podle sidry „Lech-lecha“ je však teprve po zprávě o př́chodu do Cháránu uvedena Hospodinova výzva $\mathrm{k}$ Abrahamovi, aby opustil svou zemi, rodiště a otcovský dům (Berešit 12,1) Z uvedeného sledu událostí v knize Berešit by bylo možné předpokládat, že iniciátorem ,,vyjiti““ z Úru byl Terach a místem Abramova „vyjití“ iniciované Bohem bylo město Chárán.

Cháran považoval za místo, kde dostal Abraham výzvu k odchodu rabi Moše ben Nachman (dále jen Ramban). Domníval se, že kdyby Abraham reagoval na Boží výzvu v Úru, vyšel by do zaslíbené země a jeho otec Terach by jej doprovázel z vlastní vưle. V knize Berešit je však uvedeno, že „Terach vzal svého syna... (na cestu do Kenaanu)“ a ne naopak, jak by se dalo očekávat, kdyby cestu inicioval Abraham. (Ramban k Berešit 12,12) Pro Charán jako rodiště Terachových synů svědčí také samotný text knihy Berešit, v němž posílá Abraham svého služebníka, aby přivedl ženu pro Izáka z Abrahamova rodiště ,Z města Nachorova“. (Berešit 24,4)

Raši se oproti tomu domníval, že Boží výzva $\mathrm{k}$ odchodu zazněla již v Úru. K verši „Odejdi ze své země..."Berešit 12,1) si klade otázku: „Což už odtamtud (z Uru) nevyšel se svým otcem a nepřišel až do Charánu?" (Raši k Berešit 12,1) a klade důraz na to, že v Charánu jde jen o vyjití z „domu svého otce“: „A řekl mu (Bůh): Vzdal se ještě i odtud (případně vzdal se ještě dále než jsi se už vzdálil) a vyjdi z domu svého otce.“ (Raši k Berešit 12,1)

Rambanovy názory v této věci považoval za mylné rovněž rabi Levi ben Geršon (Levi ben Geršon, 1994: 100-102), který se domníval, že Abraham sice dostal př́íkaz vyjití v Uru, ale splnění př́kazu pozdržel zastávkou v Charánu, kde si jeho otec vybudoval nový domov. Na Charán nemůže být vztaženo označení „svá země“, protože v Charánu žila rodina poměrně krátce a rozhodně jej nelze považovat za Abramovo rodiště. Texty uvedené v knize Berešit před výzvou $\mathrm{k}$ vyjití je nutné vnímat jen jako úvod kcelému Abrahamovskému cyklu. V němž vypravěč sdělí posluchači či čtenáři nejprve k čemu došlo - k vyjití rodiny z Uru Kaldejského (Ur - Chárán - zaslibéná země) a v této souvislosti také zmíní, kdo na kterém místě zemřel (Ur - Háran, Chárán - Terach). A teprve po tomto úvodu se vypravěč vrací k podrobnému vyprávění o Abrahamovu vyjití. Dokladem pro toto tvrzení je skutečnost, že Terach ještě žije, když Abraham opouští Charán, ačkoliv v textu již byla zmínka o jeho smrti. Abram se narodil, když bylo Terachovi 70 let. (Berešit 11,26) Vzhledem k tomu, že Abramovi bylo 75 let, když opustil

XLinguae, Volume 11, Issue 2, April 2018, ISSN 1337-8384, eISSN 2453-711X 
Charán, (Berešit 12,4) muselo být Terachovi v té době 145 let. Terach nemohl být v době odchodu Abrahama z Charánu mrtev, protože zemřel ve věku 205 let. (Berešit 11,32)

Ramban ve svém komentáři ke knize Berešit řeší problematiku místa Abrahamova vyjití obdobně, také podle něj je běžné, že kniha Berešit mluví o smrti otce, aby se pak vrátila $\mathrm{k}$ jeho dětem a vyprávěla co prožily ještě za života svého otce. Na první pohled se sice vyjítí z Uru jeví jako dílo otce (jak to chápe midraš Berešit raba, když vysvětluje odchod z Uru strachem Teracha o Abrahamův život, když jej chtěl usmrtit král Nimrod), ale při blížším zkoumání je patrné, že jde o reakci syna na Boží výzvu, která zazněla v Uru a nikoliv v Cháranu. (srv. Ibn Ezra 11,29; 12,1). Jak to potvrzuje rovněž Boží výrok: „Já jsem tě vyvedl z Uru Kaldejského“. (Berešit 15,7; srv. Nechemja 9,7)

Raši se ve svém komentáři ke knize Berešit domnívá, že vypravěč mluví o Terachově smrti před odchodem Abrahama z Charánu, aby zatajil skutečnost, že Abram opustil svého starého otce na posledních šedesát let jeho života (což může být čtenáři textu vnímáno jako jedna ze zkoušek poslušnosti, ale také jako porušení úcty $\mathrm{k}$ otci): „Ta věc nemusí být známa všem, aby neřekli: Abraham nezachovával úctu ke svému otci, protože ho opustil starého a šel si.“" (Raši k Berešit 11,32)

Abraham se ocitá v mezní situaci - poslušnost vůči Božímu př́ikazu stojí proti poslušnosti vưči otci (opuštění starého otce), která se tak stává skrytým pozadím narativu v sidře „Lech-lecha“. (porovnej s interpretací křest’asnkého filozofa Kierkegaarda: Kierkegaard: 1993; Kralik: 2013; Valco ) Podle Rašiho je výraz „mrtvý“ (použitý v knize Berešit o Terachovi) označením zlých a bezbožných lidí ještě za jejich života. (Raši k Berešit 11,32; srv. JT, Berachot 2,3; Berešit raba 39,7; Kohelet raba 9,1; Midraš Tanchuma, Jitro 1) Obdobně se o spravedlivých mluví jako o živých i ve chvíli, kdy už jsou mrtví. (Raši k Berešit 11,32) Spravedlivý a milosrdný otec, vůči kterému má být syn poslušný, je otec, který v rodině zobrazuje Boží vůli - je modlitebníkem, obětníkem, učitelem „torot“ (učení) a „micvot“ (př́íkazů). Poslušnost takovému otci je zároveň poslušností vůči Bohu. Terach je však představen jako hříšník, který je vlastně již za života mrtvý. Abraham proto k němu není vázán poslušností a úctou, jakou by byl vázán $\mathrm{k}$ „Živému“ - spravedlivému otci. Z tohoto důvodu zaznívá Boží př́ikaz „Jdi si““ ještě za života jeho otce a osvobozuje jej od poslušnosti vůči hřišnému otci. Podle rabínské tradice je to paradox, že se otci, který je „raša“ (svévolník) narodí syn, který je „Avraham avinu“ („Abraham, náš otec“). Tato skutečnost ukazuje, že ,člověk má svobodnou vůli. Pokud si v budoucnu bude nějaký národ stěžovat, že Hašem dal přednost Abrahamovým potomkům před ostatními národy, řekne Hašem: Avraham uplatnil svou svobodnou vůli a vybral si mě, ty jsi to mohl udělat také (Josef z Gikaltilla).“ (Katz, 2012). Hř̌šný otec se stává prototypem všech dalších hř́šných autorit (falešných proroků a falešných samozvaných vůdců).

Abrahamův otec cestu do zaslíbené země nedokončil, zůstal v Cháránu. Jeho syn se svou rodinou a Lotem jdou dál. Způsob, jak jsou obě tyto cesty popsány, ukazuje na jejich blízkost a zároveň na propastný rozdíl mezi nimi. Obě cesty mají obdobnou strukturu, stejný začátek („Terach vzal“, „Abram vzal“); výčet těch, kdo se vydávají na cestu a stejný cíl (Kenaánská země). Propastný rozdíl je v tom, že pouze Abraham je poslušný - jde na výslovný Boží rozkaz a je to také pouze on, kdo do zaslíbené země dojde.

Bůh požaduje, aby Abraham opustil svou zemi, své rodiště a otcovský dům - tři hradby, které dosud ochraňovaly jeho život. Zpřetrhat tato rodová a náboženská pouta znamená vzít na sebe riziko ohrožení sebe i své rodiny. Nachmanides ve svém komentáři ke knize Berešit uvádí, že toto trojí vymezení má Abrahamovi zabránit, aby se na své cestě předčasně nezastavil. Nestačí opustit otcův dům, musí opustit i své rodiště, nestačí opustit své rodiště, musí opustit i svou zemi. $V$ takovém př́ípadě by však mělo být pořadí opačné: dům, rodiště, země. Ramban se proto ve svém komentáři ke knize Berešit domnívá, že jde o stupňování požadavku od nejlehčího (země) k nejtěžšímu (otcovský dům) a vysvětluje tím, proč nejsou tato místa uvedena v logickém sledu, kdy člověk prakticky nejprve musí opustit svůj rodný dům, aby následně překročil hranice svého rodiště a nakonec i své země. Podle Tóry Bůh Abrahama v Kenaanu žádá, aby se rozloučil se svou minulostí, což je snadnější než se rozloučit se svou budoucností, když bude Bůh od Abrahama žádat (v následující sidře „Vajera“) jeho milovaného syna. Obě vyprávění se v některých věcech podobají. V obou př́padech Bůh zatajuje Abramovi přesné určení místa. Přri výzvě k vyjití nemluví o Kenaanu, ale pouze o „zemi, kterou ti ukážu“ (Berešit 12,1) a v druhém príípadě 
mluví o „hoře o které ti řeknu“. (Berešit 22,2) V obou případech zazní v úvodu výzva „lech-lecha“, jednou do země zaslíbené, podruhé „do země Mória“. (Berešit 22,2) A v obou případech zaznívá hned od začátku ujištění „,bude to pro tebe dobré“. Přesto jsou však obě rozhodnutí velmi těžká, první na hranici lidských možností druhé dokonce až za ní.

Bůh Abrahama vyzývá k rozloučení s minulostí i budoucností, ale nevyzývá jej $\mathrm{k}$ rozloučení $\mathrm{s}$ prítomností $\mathrm{v}$ zaslíbené zemi. Bůh dopustí, aby v zaslíbené zemi (místo očekávaného blahobytu) nastal hlad, kterým tak často Bůh zkouší i trestá člověka. Podle rabínské tradice postihl takový hlad naprríklad Adama, poté co bůh proklel zemi, Abrahama v zaslíbené zemi před sestupem do Egypta, Jicchaka před odchodem k Pelištejcům, syny Jákova, kteří musí jít nakoupit zrní do Egypta, Elimelecha, který musí odejít sesvou rodinou do Moábu, Davida (tehdy trval hlad tři roky), Elijáše a Elíšu. Hlad, který je Božím trestem čas od času postihuje lidi ruzných oblastí. Poslední takový hlad nebude ani po chlebu ani po vodě, ale po slyšení Božích slov a postihne svět před příchodem Mesiáše. (Ginzberg: 2004). Zjevuje tak Abrahamovi, že zaslíbená země nebude zahrabou Eden. Také v zaslíbené zemi se člověk setká s trápením. (BT, Berachot $5 \mathrm{a}$ ) V období hladu Bůh Abrahamovi neř́ká, aby zaslíbenou zemi opustil. Odchod Abrahama do Egypta je jen jeho rozhodnutím, které lze dokonce vyhodnotit jako neposlušnost. Abraham se nezlobí, nereptá, nestěžuje si, nevyčítá Bohu kam jej přivedl, (Berešit raba 40,2) ale hledá pomoc v bohaté a úrodné zemi, která je však považována za chrám pohanských božstev. Abraham sestoupil (,jarad“) do Egypta a byl to jistě sestup nejen fyzický, ale především duchovní (obdobně se sestupuje do šeolu). Abrahamovo rozhodnutí sestoupit se ukáže nepř́liš štastným, protože přivede jeho ženu do blízkosti hříchu. Bůh sám její čest zachrání, když potrestá faraóna strašnými ranami. Podle Rambanova komentáře ke knize Berešit byl tento Abrahamův čin „velkým hříchem“ a trestem za tuto jeho nedůvěru byl čtyřistaletý pobyt potomků Abrahama v egyptském otroctví. (Ramban k Berešit 12,10. Mnozí s ním však nesouhlasí, protože člověk má právo chránit aktivně svůj život a ne pouze trpně očekávat zázrak. Nachmanovo stanovisko odmítal např́iklad Jehuda ben Becalel z Prahy (Maharal, Gevurot Hašem, 9), který se domníval, že v případě potrestání „zapření Sáry“ tak přísným trestem, jistě by se Abram nedopustil stejného prohřešku u Abimelecha, jak se uvádí $\mathrm{v}$ následující sidře. Obdobně se $\mathrm{k}$ této problematice ve svém komentári $\mathrm{k}$ Tóře staví také Raši, Radag, Ralbag, z pozdějších komentátorů pak nap̌r. Samuel Raphael Hirsch).

Maharal (Jehuda ben Becalel z Prahy, Rabi Loewe) oproti tomu viděl důvod v potrestání potomků Abrahama vyhnanstvím v nedůvěre skryté v jeho otázce: „Panovníku Hospodine, podle čeho poznám, že ji (zemi) obdržím?" (Berešit 15,8)

Rabíni interpretují události, které se týkaly Abrahama (obdobně také dalších praotců) jako znamení toho, co se stane jeho potomkům. Midraš Tanchuma, Lech lecha 9. Berešit raba 40 (oproti Midraši Tanchuma) vnímá tento vztah kauzálně (př́ičina - následek), nejde o pouhé znamení pro syna, ale o vytváření jejich budoucnosti. Podle Berešit raba to jsou to otcové, kteří vědomými skutky připravují budoucí cestu svých dětí. Ramban tato „znamení synům“ chápe stejně jako symbolické úkony proroků (např. Jirmejahu 51,63-62, Melachim bet 13,17). Ramban k Berešit 12,7; 12,10). Otec se stává prorockým „znamením pro syny“ (,siman levanim“). Proroctví se tak děje nejen slovem nýbrž také symbolickým činem. Bůh člověku nabízí určitou možnost budoucnosti, poslušnost vede k naplnění této možnosti, neposlušnost vede $\mathrm{k}$ jejímu zmaření.

\section{Závěr}

Sidra „Lech-lecha“ mluví o stvoření budoucnosti Abrahamových potomků. Praotec (stejně i každý otec) se stává tvưrcem budoucnosti svých dětí, podle toho jaká je jeho odpověd’ na Boží výzvy. Otevřeny jsou vždy dvě cesty - poslušnost a neposlušnost. Vše, co bylo napsáno o Abrahamovi, bylo podle rabínské tradice napsáno také o jeho potomcích (Berešit raba 8,6.): Bůh si vybral Abrahama z ostatních lidí a vybral si lid z ostatních národů. (Nechemja 9,7; Devarim 14,2) Abraham dostal zaslíbení, že bude velkým národem a Izrael je velkým národem. (Berešit 12,2; Devarim 4,8) 
Začátky Abrahama jsou spojeny s vyjitím z vlasti - začátky lidu jsou spjaty s vyjitím z Egypta (Berešit 12,1; Šemot 3,17). Obdobně nalézá Ramban předznamenání babylónského exodu v př́ibězích Izáka u Abimelecha, protože toto zajetí nebylo provázeno utrpením, narozdíl od pobytu lidu v Egyptě. V této souvislosti bychom mohli položit otázku, zda předzvěstí babylónského exilu nebyl pobyt Abrahama u abimeleka. Ramban se domnívá, že nikoliv, protože tento pobyt Abrahamův byl dobrovolný, zatímco odchod Izáka k abimelekovi byl vynucen hladem, obdobně jako sestup Abrahama do Egypta (Ramban k Berešit 26,1). Pobyt v Egyptě provází veliké rány ochraňující rodinu Abrahama i později vyvolený lid. Abraham i lid vycházejí z Egypta obtíženi velkým bohatstvím. Abraham je poutník procházející tehdy známý svět - lid je poutníkem na poušti. Na cestě prochází Abraham i lid Boží školou. Cílem jejich cesty je zaslíbená země a život v ní podle učení (torot) a př́íkazů (micvot) Božích.

This article was supported by the Slovak Research and Development Agency under the contract No. APVV-16-0016".

\section{Bibliographic references:}

BIBLIA HEBRAICA. Stuttgartensia, ed. Ellinger, K., Rudolph, W. et al, Deutsche Bibelgesellschaft, Stuttgart. Deutsche Bibelgesellschaft, 1990. ISBN 13: 9783438052193.

GANZFRIED, Slomo ben Josef. 2011. Kicur sulchan aruch. Agadah. ISBN 978-8087571-00- 2 .

GANZFRIED, Slomo ben Josef. 2012. Kicur sulchan aruch. II. Agadah. ISBN 978-8087571-01- 9 .

GINZBERG, L. 2004. The Legends of the Jews. Kessinger Publishing, 978-1419169069.

KATZ, S., 2012. The Chested of Avraham. Parshas Lech Lecha. Torah.

KIERKEGAARD, S. 1993. Bazen a chveni. Nemoc k smrti. Praha: Svoboda. ISBN 80205-0360-9.

KRALIK, R. 2013. Kierkegaardův Abrahám: Kierkegaardova interpretace Abrahámovy víry. Ljubljana: KUD Apokalipsa. ISBN 978-961-6894-30-2.

PESCHKE, K.H. 1999. Krestanska etika. Praha: Vysehrad, ISBN 80-7021-331-0.

LEVI ben Gerson. 2014. /Ralbag-Gersonides/, Commentary on Sefer Beresit, Morad HaRav Kook.

SLADEK, P. 2008. Mala encyklopedie rabinskeho judaismu, Praha: Libri.

SLIVKA, D. 2015. Hebraic scriptural hermeneutics in the ancient Hellenistic world as the basic approach of early Christians. In: European Journal of Science and Theology, vol. 11, n. 5, pp. 87-96, ISSN 1841-0464.

TANDLICH, T. 2015. The Jewish religion and culture - milestone for the past, present and future. In: XLinguae, vol. 8, n. 1, pp. 101-104. ISSN 1337-8384.

VALCO, M. 2017. Kierkegaardov Abraham cez optiku Dietricha Bonhoeffera. In Kierkegaard and the Crisis of the Contemporary World. Acta Kierkegaardiana. (Eds. Roman Kralik et al.) Toronto: University of Toronto. ISBN 978-0-9878168-4-9, pp. 366372.

מקראות גדולות, Mikraot gedolot: hamishah humshe Torah im Targum Onkelos... veim shenayim vearbaim perushim, I.-V., Vilna: Ram, 1912.

Ibn Ezra's Torah Commentary, Available online:

http://mg.alhatorah.org/Dual/Ibn_Ezra_First_Commentary/1.1\#t1e0n6

Rashi's Torah Commentary, http://alhatorah.org/Commentators:Rashi_Leipzig

ם\&quot; Misne Tora, Available online: http://www.mechonmamre.org/i/0.htm

שישה סדרי משנה שישה סדרי תוספתא משת תלמרי

שישה סדרי תלמוד בבלי mamre.org/b/l/10.htm

תלמוד ירושלמי, Jeruzalemsky talmud (JT), Available online: http://www.mechonmamre.org/b/r/ro.htm 
תרגום אונקלוס מנוקד, Targum Onkelos, Available online:http://www.mechonmamre.org/i/t/u/u0.htm

Words: 5263

Characters: $34480(19,15$ standart pages)

ThDr. Marie Roubalová, ThD.

Hussite Theological Faculty, Charles University in Prague,

Pacovská 350/4, 14000 Praha

Czech Republic

marie.roubalova@htf.cuni.cz

Prof. Bojan Žalec, PhD.

Faculty of Theology, Institute of Philosophy and Social Ethics,

University of Ljubljana,

Poljanska c. 4, SI-1000 Ljubljana

Slovenia

bojan.zalec@guest.arnes.si

Prof. Dr. Roman Králik, ThD.

Faculty of Arts, Constantine the Philosopher University in Nitra, Hodzova 1, 94901 Nitra

Slovakia

rkralik@ukf.sk 